\title{
Molecular characterization of Cryptococcus neoformans recovered from pigeon droppings in Rivera and Neiva, Colombia
}

\section{Caracterización molecular de Cryptococcus neoformans recuperado de guano de palomas en Rivera y Neiva, Colombia}

\author{
Camila Virviescas $B^{1}$ Ing Ambiental; María Aragón $\mathrm{F}^{1}$ Ing. Ambiental; Luis Vásquez A3 M.Sc; \\ Fabiola González C 3 M.Sc; Patricia Escandón H² M.Sc; Hans Castro S1* Ph.D.
}

${ }^{1}$ Corporación Universitaria del Huila - CORHUILA, Facultad de Ingenierías, Programa de Ingeniería Ambiental, Grupo de Aplicación e Investigación Ambiental - GAIA, Calle 8 \# 32 - 49 Neiva, Colombia. 2Instituto Nacional de Salud, Grupo de Microbiología, Calle 26 \# 51-20 Bogotá, Colombia. ${ }^{3}$ Universidad del Cauca, Centro de Estudios en Microbiología y Parasitología CEMPA, Calle 5 No 4-70 Popayán, Colombia. *Correspondencia: hans.castro@corhuila.edu.co

Received: February 2018; Accepted: July 2018.

\begin{abstract}
Objective. Characterize phenotypically and genotypically isolates of Cryptococcus neoformans and Cryptococcus gattii that can be found in feces of pigeons (Columba livia) and in soil, leaves and detritus of almond trees (Terminalia catappa) in the municipalities of Neiva and Rivera, Colombia. Materials and methods. One hundred and eighteen samples were collected in 13 specific areas, characterized by the presence of almond trees and high density of birds, between January and June 2016. Incubation of the processed samples was done at $27^{\circ} \mathrm{C}$ for two weeks using Guizottia abyssinica agar. The phenotypic characterization, the species determination and the subsequent molecular typing was done using PCR fingerprinting with (GTG) ${ }_{5}$ primer and Restriction Fragment Length Polymorphism with URA5 and SJ01 primers. Results. A 5.9\% of the samples from pigeon feces were positive for $C$ neoformans var. grubii (VNI molecular pattern). Samples collected from almond tree detritus were not positive for any of the species studied. Conclusions. The isolation of $\mathrm{C}$. neoformans from pigeon droppings in the municipalities of Rivera and Neiva adds to the scarce knowledge about this pathogen in the department of Huila, revealing the importance of continuing with these type of studies, not only in the environment but in the exposed population.
\end{abstract}

Keywords: C. neoformans var. grubii; detritus; environment; genotype; pigeon droppings (Source: MeSH).

\section{RESUMEN}

Objetivo. Caracterizar fenotípica y genotípicamente aislados de Cryptococcus neoformans y Cryptococcus gattii presentes en heces de palomas (Columba livia) y en suelo, hojas y detritos de árboles de almendro (Terminalia catappa) en los municipios de Neiva y Rivera, Colombia. Materiales y métodos. Ciento dieciocho muestras fueron recogidas en 13 zonas caracterizadas por la presencia de árboles de almendro y alta densidad de palomas, entre enero y junio de 2016. La incubación de las muestras procesadas se hizo a $27^{\circ} \mathrm{C}$ durante dos semanas en agar Guizottia abyssinica. La caracterización fenotípica, la determinación de la especie y la posterior tipificación molecular se hizo mediante PCR huella digital con el iniciador (GTG) $)_{5}$ y Polimorfismos de Longitud de Fragmentos de Restricción empleando los iniciadores URA5 y Sj01. Resultados. Un 5.9\% de las muestras de heces de palomas fueron positivas para C. neoformans var grubii (patrón molecular VNI). Las muestras recolectadas a partir de almendros no fueron positivas para ninguna de las dos especies estudiadas. Conclusiones. El aislamiento de C. neoformans de heces de palomas (Columba livia) en los municipios de Rivera y Neiva aporta al escaso conocimiento que se tienen acerca de este patógeno en el departamento del Huila, revelando la importancia de continuar con estos estudios, no solo en el ambiente sino en la población expuesta.

Palabras clave: Ambiente; C. neoformans var. grubii; detritos; genotipo; heces de palomas (Fuente: MeSH). 


\section{INTRODUCTION}

Cryptococcosis is a severe opportunistic fungal infection caused by an encapsulated yeast fungus. The disease has been related to the exposure of patients to contaminated environments, it is generated by two complex of species: C. neoformans and C. gattii: C. neoformans, consisting of the varieties grubii (serotype A) and neoformans (serotype D) and a hybrid (serotype AD); and C. gattii with serotypes B and C (1).

C. neoformans and C. gattii develop a specific biotrophic association with host plants, which during their flowering generate the dispersion of the aerial basiodospores. These aerial basiodospores remain in the environment for short periods, helping to the distribution and transmission of infectious propagules for humans and animals (2). Birds that have some association with the host plant can pass the fungus through their intestine and remove capsulated yeast in feces (3). The fungus has the ability to be present on surfaces through the bird's excreta, which can endure for several years, allowing these habitats to act as important sources for the dried yeast dispersion (4).

In Colombia, there is an evidence of cryptococcosis incidence increase, especially in the immunosuppressed population affected by HIV, between the years 1997 - 2016 there was an incidence of 0.23 cases / 100,000 inhabitants reported in the general population, with an increase to 1.1 cases / 1000 inhabitants living with AIDS (5). According to the Colombian Cryptococcosis Study Group publication, there are endemic areas for its development, as it is presented in the department of Norte de Santander. However, other departments such as Huila report very few cases, 32 cases for 20 years, suggesting the need to study this mycosis and its etiological agents in this region of the country.

A series of molecular techniques for the molecular epidemiology study of $C$. neoformans and $C$. gattii, which allow to characterize genotypically isolated, have been described $(6,7)$. Through the use of PCR fingerprinting (8) and Restriction Fragment Length Polymorphisms (RFLP), eight main molecular patterns have been proposed. VNI and VNII patterns correspond to $C$. neoformans var. grubii; VNIII corresponds to the hybrid AD and VNIV corresponds to $C$. neoformans var. VGI, VGII, VGIII and VGIV molecular patterns correspond to C. gattii.

A recent study published in 2015 by Mak et al (9), it was identified through the creation of an Ecological Niche Model, that different departments of Colombia such as Huila, might be an area of frequent human cases or environmental isolations of C. neoformans and C. gattii, due to their ecoepidemiological characteristics (9).

\section{INTRODUCCIÓN}

La criptococosis, una infección micótica oportunista grave causada por un hongo levaduriforme y encapsulado, está asociada con la exposición de los pacientes a ambientes contaminados con el patógeno, y cuyos agentes causales se agrupan, según la más reciente proposición, en el complejo de especies $C$. neoformans: C. neoformans, conformada por las variedades grubii (serotipo A) y neoformans (serotipo D) y un híbrido (serotipo AD); y el complejo de especies C. gattii (serotipos B y C)(1).

Tanto C. neoformans como C. gattii desarrollan una asociación biotrófica específica con plantas hospederas como el almendro, que se convierten en un hábitat ideal para la dispersión del hongo al ambiente, facilitando la distribución y transmisión de propágulos infecciosos para el humano y animales (2). Las aves pueden ser portadoras del hongo a través de su intestino y eliminar levaduras capsuladas a través de sus heces (3). El hongo tiene la capacidad de sobrevivir presente en diferentes superficies en el ambiente y permanecer durante varios años, permitiendo que estas muestras actúen como fuentes importantes para la dispersión de levaduras secas (4).

En Colombia existe evidencia de la importancia de la enfermedad en la población inmunosuprimida e inmunocompetente; es así como para el período 1997-2016 se reportaron incidencias de 0,23 casos/100.000 habitantes en la población general, con un aumento a 1,1 casos/1000 habitantes viviendo con el sida (5). Según un estudio del Grupo Colombiano para el Estudio de la Criptococosis, existen zonas endémicas para esta micosis, tal como es el caso del departamento Norte de Santander; mientras que otros departamentos como el Huila reportan tan solo 32 casos en un período de 20 años, lo cual sugiere la necesidad de estudiar esta micosis y sus agentes etiológicos en esta región del país.

Se han descrito una serie de técnicas moleculares para el estudio de la epidemiologia molecular de C. neoformans y C. gattii, las cuales permiten caracterizar genotípicamente los aislados $(6,7)$. Mediante el uso de PCR huella digital (8) y Polimorfismos de Longitud de Fragmentos Amplificados (RFLP, por sus siglas en inglés Restriction Fragment Lenght Polymorphism), se propone que los miembros de los complejos se agrupen en ocho patrones moleculares principales. Los patrones VNI y VNII corresponden a C. neoformans var. grubii; VNIII corresponde al híbrido AD y VNIV corresponde a $C$. neoformans var. neoformans. Por otro lado, los patrones moleculares VGI-VGIV corresponden a C. gattii.

En un estudio publicado en el 2015 por Mak et al (9), se identificaron mediante la creación de un Modelo de Nicho Ecológico, que establece que diferentes departamentos de Colombia tal como el Huila, pueden ser áreas propensas de presentar 
According to the above, a search for the species C. neoformans and C. gattii was carried out in environmental samples collected in the department of Huila, in municipalities of Neiva and Rivera and a molecular typing of the isolations was realized in order to conclude the circulation of this pathogen in the environment.

\section{MATERIALS AND METHODS}

Study area. Neiva is the capital city of HuilaColombia; it is located between the Central and Eastern Mountain in a plain on the eastern margin of the Magdalena River and the valley, crossed by The Ceibas and The Gold rivers. One of the Neiva characteristics is its high temperature: with an average temperature of $27.7^{\circ} \mathrm{C}$. 2059'55 North latitude and $75^{\circ} 18^{\prime} 16$ West longitude. Neiva has an altitude of 442 meters above sea level and it has an approximate population of 345.911 inhabitants according to the DANE projection for 2017 (10). On the other hand, Rivera is located in the department of Huila too. The municipal seat altitude is 700 m.a.s.l. with an average temperature of $25^{\circ} \mathrm{C}$.

Study design. Observational and descriptive cross-sectional study, in which a sampling was carried out with 12 points distributed in different areas of Neiva and Rivera municipalities, prioritizing places where there were greater observation of birds and congregation of almond trees (Terminalia catappa) (Table 1$)$.

Table 1. Collection of samples from pigeon feces (Columba livia) and plant material associated with Terminalia catappa.

\begin{tabular}{|c|c|c|c|}
\hline Sample type & Location & Coordinates & Total samples \\
\hline \multirow[t]{6}{*}{ Feces of pigeons } & $\begin{array}{c}\text { Finca Villa } \\
\text { Constanza, Rivera }\end{array}$ & $\begin{array}{c}2^{\circ} 45^{\prime} 36.07^{\prime \prime} \mathrm{N} \\
75^{\circ} 17^{\prime} 19.30^{\prime \prime O}\end{array}$ & 19 \\
\hline & $\begin{array}{c}\text { Finca Villa Mafe, } \\
\text { Rivera }\end{array}$ & $\begin{array}{c}2^{\circ} 46^{\prime} 15.60^{\prime \prime} \mathrm{N} \\
75^{\circ} 16^{\prime} 25.71^{\prime \prime} \mathrm{W}\end{array}$ & 5 \\
\hline & $\begin{array}{c}\text { Monta llantas, } \\
\text { Neiva }\end{array}$ & $\begin{array}{l}2^{\circ} 55^{\prime} 20,47^{\prime \prime} \mathrm{N} \\
75^{\circ} 17^{\prime} 5,59^{\prime \prime} \mathrm{W}\end{array}$ & 12 \\
\hline & $\begin{array}{c}\text { Parque Guaduales, } \\
\text { Neiva }\end{array}$ & $\begin{array}{c}2^{\circ} 56^{\prime} 28,0^{\prime \prime} \mathrm{N} \\
75^{\circ} 15^{\prime} 33,2^{\prime \prime} \mathrm{W}\end{array}$ & 23 \\
\hline & $\begin{array}{c}\text { Barrio Víctor Félix, } \\
\text { Neiva }\end{array}$ & $\begin{array}{c}2^{\circ} 56^{\prime} 21,2^{\prime \prime} \mathrm{N} \\
75^{\circ} 14^{\prime} 51,1^{\prime \prime} \mathrm{W}\end{array}$ & 20 \\
\hline & Plaza Cívica, Neiva & $\begin{array}{c}2^{\circ} 55^{\prime} 29,8^{\prime \prime} \mathrm{N} \\
75^{\circ} 17^{\prime} 29,4^{\prime \prime} \mathrm{W}\end{array}$ & 7 \\
\hline \multirow[t]{7}{*}{$\begin{array}{l}\text { Detritus of Almond } \\
\text { tree (Leaves, } \\
\text { fruits and soil) }\end{array}$} & $\begin{array}{l}\text { Barrio Álamos } \\
\text { Norte, Neiva }\end{array}$ & $\begin{array}{c}2057^{\prime} 21,7^{\prime \prime} \mathrm{N} \\
75^{\circ} 16^{\prime} 50,5^{\prime \prime} \mathrm{W}\end{array}$ & 4 \\
\hline & $\begin{array}{c}\text { Barrio Granjas, } \\
\text { Neiva }\end{array}$ & $\begin{array}{c}2^{\circ} 56^{\prime} 33,2^{\prime \prime} \mathrm{N} \\
75^{\circ} 17^{\prime} 27,1^{\prime \prime} \mathrm{W}\end{array}$ & 4 \\
\hline & $\begin{array}{c}\text { Barrio La Gaitana, } \\
\text { Neiva }\end{array}$ & 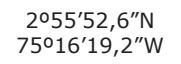 & 4 \\
\hline & $\begin{array}{c}\text { Barrio Quebraditas, } \\
\text { Neiva }\end{array}$ & $\begin{array}{l}2^{\circ} 55^{\prime} 23,1^{\prime \prime} \mathrm{N} \\
75^{\circ} 16^{\prime} 49,1 \mathrm{~W}\end{array}$ & 6 \\
\hline & $\begin{array}{c}\text { Avenida } \\
\text { Circunvalar, Neiva }\end{array}$ & $\begin{array}{c}2^{\circ 0} 55^{\prime} 31,9^{\prime \prime} \mathrm{N} \\
75^{\circ} 17^{\prime} 36,1^{\prime \prime} \mathrm{W}\end{array}$ & 7 \\
\hline & $\begin{array}{c}\text { Barrio Prado Alto, } \\
\text { Neiva }\end{array}$ & $\begin{array}{c}2055^{\prime} 50,7^{\prime \prime} \mathrm{N} \\
75^{\circ} 15^{\prime} 59,0^{\prime \prime} \mathrm{W}\end{array}$ & 3 \\
\hline & $\begin{array}{c}\text { Finca Villa } \\
\text { Constanza, Rivera }\end{array}$ & $\begin{array}{c}2^{\circ} 45^{\prime} 36.07^{\prime \prime} \mathrm{N} \\
75^{\circ} 17^{\prime} 19.30^{\prime \prime O}\end{array}$ & 4 \\
\hline \multicolumn{3}{|c|}{ Total } & 118 \\
\hline
\end{tabular}

frecuentes casos en humanos o áreas con un número considerable de aislamientos ambientales de C. neoformans y C. gattii, por sus características eco-epidemiológicas.

Teniendo en cuenta lo anterior, el presente estudio tuvo como objeto realizar la búsqueda de las especies $C$. neoformans y $C$. gattii en muestras ambientales recolectadas en el departamento del Huila, en los municipios de Neiva y Rivera, y realizar la tipificación molecular de los aislamientos con el fin de determinar la circulación de estos complejos de especies en el ambiente.

\section{MATERIALES Y MÉTODOS}

Área de estudio. Neiva es la ciudad capital del Huila, Colombia, está ubicada entre la Cordillera Central y Oriental. Una de las características del municipio son sus altas temperaturas, en promedio se encuentra en $27,7^{\circ} \mathrm{C}$. Neiva se encuentra ubicada a una latitud 2059'55 Norte, y longitud 75018'16 Oeste, presenta una altitud de 442 m.s.n.m. y tiene una población aproximada de 345.911 habitantes de acuerdo con la proyección del Departamento Administrativo Nacional de Estadística (DANE) para el 2017 (10). Por otro lado, Rivera, se encuentra ubicado también en el departamento del Huila. La altitud de la cabecera municipal está a 700 m.s.n.m. con una temperatura promedio de $25^{\circ} \mathrm{C}$.

Diseño del estudio. Este es un estudio observacional y descriptivo de corte transversal, en el cual se realizó un muestreo con 13 puntos distribuidos en diferentes zonas de los municipios de Neiva y Rivera, dando prioridad a lugares donde se encontraron mayor observación de aves y congregación de árboles de almendro (Terminalia catappa) (Tabla 1).

Recolección de muestras ambientales. Se recolectaron un total de 118 muestras, 86 de excremento de palomas (Columba livia) y 32 provenientes de frutos, hojas y detritos de árboles de almendros (Terminalia catappa). En cada sitio de muestreo se hizo una recolección de aproximadamente $10 \mathrm{~g}$ de excretas de paloma; para el caso de los árboles, se recolectaron tres muestras de $10 \mathrm{~g}$ de cada detrito, los cuales se almacenaron en bolsas plásticas de cierre tipo hermético, se rotularon e inmediatamente se enviaron a temperatura ambiente al Grupo de Microbiología del Instituto Nacional de Salud para su procesamiento.

Procesamiento de las muestras. Las muestras de heces y de materia orgánica y suelo de almendros fueron procesadas mediante técnicas convencionales empleando la técnica de la extracción del microorganismo mediante suspensión en buffer fosfato salino y posterior siembra en medio de cultivo agar Guizotia abyssinica suplementado con bifenilo y antibióticos (11). Estas placas se incubaron a $27^{\circ} \mathrm{C}$ durante dos semanas con observación 
Collection of environmental samples. A total of 118 samples were collected: 86 pigeon droppings (Columba livia) and 32 from detritus of fruits, leaves and the almond trees soil (Terminalia catappa). A collection of approximately $10 \mathrm{~g}$ of pigeon excreta was performed at each sampling site. In the case of trees, three samples of $10 \mathrm{~g}$ of each detritus were collected and stored in labeled airtight plastic bags and then sent to the Grupo de Microbiología from Instituto Nacional de Salud.

Sample processing. The feces samples, the organic matter and almond soil were processed by conventional techniques using the saline phosphate buffer extraction technique and subsequent seeding in Guizotia abyssinica agar culture medium supplemented with biphenyl and antibiotics (11). These plates were incubated at $27^{\circ} \mathrm{C}$ for a month with daily observation; suspect Cryptococcus colonies, characterized by a brown tonality in the culture medium, were reseeded in Sabouraud agar for identification by conventional techniques: urease production, nitrate determination and capsule visualization and capsule visualization. Subsequently, the specie was determined by sowing on Canavanin Glycine - Bromothymol Blue (CBG) agar (11). If more than one presumptive colony was observed for each sample, the total number of colonies present was taken for its identification.

Molecular typing. The high molecular weight DNA was extracted from the $C$. neoformans species complex isolates, according to Casali et al (12).

PCR Digital Fingerprint and Restriction Fragment Length Polymorphism (RFLP). The molecular pattern of each isolation was determined by PCR fingerprinting using a GelDoc XR system (Bio-Rad Laboratories, USA) with the primer (GTG) 5, and Restriction Fragment Length Polymorphism (RFLP) of the URA5 gene, with the primers URA5 and SJ01. The molecular pattern of each isolate was assigned by comparison with the control strains corresponding to the VNI-VNIV and VGI-VGIV standards, obtained from the molecular mycology laboratory of the University of Sydney, Westmead Hospital (13). The PCR products were visualized on a $2.0 \%$ agarose gel stained with ethidium bromide, by electrophoretic run at $100 \mathrm{~V}$ for 3 hour.

\section{RESULTS}

From a total of 118 processed samples, $8(6.8 \%)$ were positive for $C$. neoformans var. grubii, all associated with bird excrement, both from the municipality of Rivera and from the samples collected in Neiva, with a total of 40 colonies identified in their entirety as var. grubii. The fungus diaria; las colonias sospechosas de Cryptococcus, caracterizadas por presentar una coloración café en el medio de cultivo, se resembraron en agar Sabouraud para su identificación mediante el uso de técnicas convencionales: producción de ureasa, reducción de nitratos y presencia de la cápsula característica del hongo. Posteriormente, se determinó la especie mediante siembra en agar Canavanina Glicina Azul de Bromotimol (CGB) (11). En caso de que se observara más de una colonia presuntiva para cada muestra, se tomaba el total de las colonias presentes en el medio de cultivo para su posterior identificación.

Tipificación molecular. Se aisló el ADN de alto peso molecular de los aislados previamente confirmados como $C$. neoformans según la metodología descrita por Casali et al (12).

PCR Huella digital y Polimorfismos de Longitud de Fragmentos de restricción (RFLP). EI patrón molecular de cada aislado se determinó mediante PCR huella digital con el iniciador (GTG) ${ }_{5}$, y Polimorfismo de Longitud de Fragmentos de Restricción (RFLP) del gen URA5, con los iniciadores URA5 y SJ01. El patrón molecular de cada aislado se asignó mediante comparación con las cepas control correspondiente a los patrones VNI-VNIV y VGI-VGIV, obtenidas del laboratorio de micología molecular de la Universidad de Sydney, Westmead Hospital (13). Los productos de PCR se visualizaron en un gel de agarosa al $2.0 \%$ teñido con bromuro de etidio, mediante un corrido electroforético a $100 \mathrm{~V}$ durante 3 horas.

\section{RESULTADOS}

De un total de 118 muestras procesadas, $8(6.8 \%)$ fueron positivas para $C$. neoformans var. grubii, todas asociadas a excremento de aves, tanto del municipio de Rivera como de las muestras recolectadas en Neiva, para un total de 40 colonias identificadas en su totalidad como var. grubii. No se recuperó el hongo a partir de muestras de árboles; C. gattii no fue aislado de ninguna de las muestras recolectadas.

En cuanto a la tipificación molecular, todos los aislados se agruparon en el patrón molecular VNI, tanto por PCR huella digital (Figura 1) como por RFLP del gen URA5, en la cual se observa la asignación de patrones de acuerdo con los aislados empleados como control.

\section{DISCUSIÓN}

En Colombia, los estudios ambientales han reportado los serotipos A y $B$ como los más prevalentes. Se reportan una serie de estudios que revelan la presencia tanto de $C$. neoformans como C. gattii en diferentes tipos de muestras $(9,11)$. Lo encontrado en este estudio coincide con los reportes realizados previamente a nivel mundial y en Colombia, en los cuales se reporta que los 
was not recovered from tree samples; C. gattii was not isolated from any of collected samples.

In according to molecular typing, all the isolates were grouped in the molecular VNI pattern, both by PCR fingerprinting (Figure 1 ) and RFLP of URA5 gene, in which the assignment of patterns, according to the isolates used as control, is observed.

\section{DISCUSSION}

In Colombia, environmental studies have reported the serotypes A and B as most prevalent. A series of studies were reported revealing the presence of both $C$. neoformans and $C$. gattii in different types of samples $(9,11)$. The results of this study coincide with the reports previously made worldwide and in Colombia, in which it is reported that bird droppings are an important habitat for yeast, considering that this substrate has high levels of xanthine, urea, uric acid and creatinine, compounds that stimulate the fungus growth $(3,4,14)$.

The presence of $C$. gattii serotype $C$ in almond trees was identified for first time in Cúcuta, capital of Norte de Santander (15). In this study, it was not possible to isolate this species from this habitat, so it is advisable to continue sampling in this area, expanding the spectrum of possible arboreal niches that can act as host to the fungus.

Although the number of isolates recovered in this study was small, this is the first report on the isolation of the $C$. neoformans variety grubii from the environment in the city of Neiva, Huila. With this study, the reservoir of the species $C$. neoformans is present in domesticated birds were evidenced, which generates a high probability that this infection spreads to the community, especially to the population with some type of immunosuppression.

While there were not isolated positive strains of the C. gattii species in the sampled areas of almond cuttings, it is important to continue with new research on neither recovery of $C$. neoformans from tree samples, the epidemiology in this region, in order to design strategies for prevention and control of this fungal infection. A study on opportunistic infections in patients with HIV conducted at the Hospital University in Neiva for 2007-2012 reveals that $8 \%$ of patients died of cryptococcosis infection, being $76.5 \%$ positives for AIDS (16). Thus, it is necessary to obtain additional information about the hospitalization causes of the patients with AIDS and the behaviour of opportunistic infections, which allows improving medical practice through early diagnosis and the appropriate treatment of this condition and its complications.

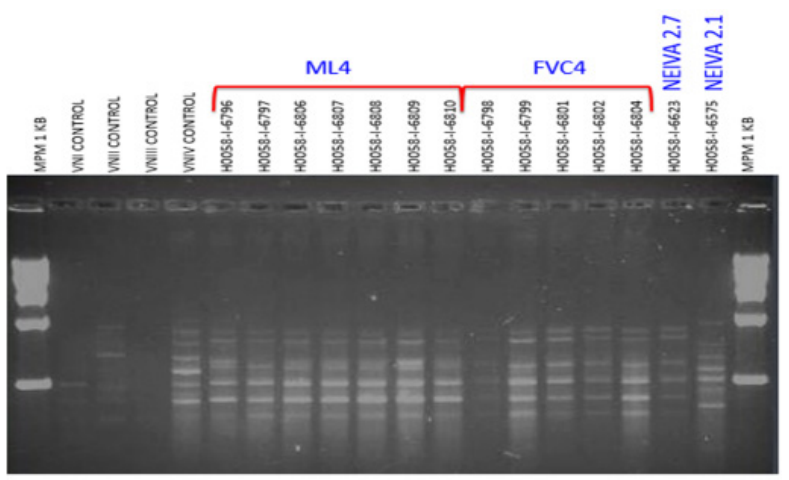

Figure 1. PCR fingerprint with the primer $(\mathrm{GTG})_{5}$ of environmental PCR fingerprinting isolates of Cryptococcus neoformans recovered from bird droppings in the city of Neiva.

excrementos de aves son un hábitat importante para la levadura, teniendo en cuenta que este sustrato posee altos niveles de xantina, urea, ácido úrico y creatinina, compuestos que estimulan el crecimiento del hongo $(3,4,14)$.

Contrario a lo reportado previamente en el país, específicamente en Cúcuta, capital de Norte de Santander, donde se identificó por primera vez la presencia de $C$. gattii serotipo $C$ en arboles de almendro (15), en este estudio no se logró aislar esta especie a partir de este hábitat, por lo cual es recomendable continuar con los muestreos en esta zona, ampliando el espectro de los posibles nichos arbóreos que puedan actuar como hospederos del hongo.

Aunque el número de aislados recuperados en este estudio fue bajo, este es el primer reporte sobre el aislamiento del $C$. neoformans var. grubii del ambiente en la ciudad de Neiva, Huila. Con este estudio se evidenció que el reservorio de la especie C. neoformans está presente en aves silvestres, específicamente en la paloma común, lo cual genera una alta probabilidad de que esta infección se propague a la comunidad, especialmente a la población con algún tipo de inmunosupresión expuesta a estas fuentes ambientales comúnmente visitadas.

A pesar que no se recuperaron aislados de la especie C. gattii en las muestras recolectadas, así como no hubo recuperación de $C$. neoformans a partir de muestras de árboles, es importante seguir con nuevas investigaciones sobre la epidemiología en esta región para diseñar estrategias de prevención y control sobre esta infección micótica. Un estudio sobre infecciones oportunistas en pacientes con VIH realizado en el hospital universitario de Neiva en el período 2007-2012, revela que de un total de 286 pacientes estudiados, aproximadamente el $19.3 \%$ fueron diagnosticados con criptococosis, siendo el $76.5 \%$ positivos para el VIH (16). Por esta razón, se necesita mayor información sobre las causas de hospitalización de los pacientes con VIH y el comportamiento de las infecciones 
Cryptococcosis is becoming increasingly important in diseases of public health importance worldwide. Colombia, despite not including this disease within those events of interest in public health, reports incidences of up to 1.1 cases / 1000 inhabitants living with AIDS (5). Therefore it is of great importance to continue with the surveillance of cryptococcosis and strengthen passive participation in those departments with low notification such as Huila; in which, as presented in this research, the presence of the main etiological agent of the disease is evident in the environment, being an important finding having present that the the infection is acquired by exposure to the spores of the fungus present in the environment.

\section{Conflict of interests}

The authors declare that there is no conflict of interest that calls into question the validity of the investigation. oportunistas, que permita mejorar la práctica médica a través del diagnóstico temprano y del tratamiento apropiado de esta condición y sus complicaciones.

La criptococosis adquiere cada día una mayor relevancia dentro de las enfermedades de importancia en salud pública a nivel mundial. Colombia, a pesar de no incluir esta enfermedad dentro de aquellos eventos de interés en salud pública, reporta incidencias de hasta 1.1 casos/ 1000 habitantes que viven con sida (5). Por lo cual es de gran importancia continuar con la vigilancia de la criptococosis y fortalecer la participación pasiva en aquellos departamentos con baja notificación como el Huila; en el cual, como se presenta en esta investigación, la presencia del principal agente etiológico de la enfermedad se evidencia en el medio ambiente, siendo un hallazgo importante si se tiene en cuenta que la infección se adquiere por la exposición a las esporas del hongo presentes en el ambiente.

\section{Conflicto de intereses}

Los autores declaran que no existe conflicto de interés que ponga en duda la validez de la investigación.

\section{REFERENCES}

1. Kwon-Chung $\mathrm{KJ}$, Bennett JE, Wickes $\mathrm{BL}$, Meyer W, Cuomo CA, Wollenburg KR, et al. The Case for Adopting the "Species Complex" Nomenclature for the Etiologic Agents of Cryptococcosis. mSphere. 2017; 2(1):e00357-16. DOI: https://doi. org/10.1128/mSphere.00357-16

2. Lucas S, Martins MdaL, Flores O, Meyer W, Spencer-Martins I, Inácio J. Differentiation of Cryptococcus neoformans varieties and Cryptococcus gatti using CAP59-based loopmediated isothermal DNA amplification. Clin Microbiol Infec. 2010; 16(6):711-714.

3. Rosa G, Merlini LS, Bessi WH, Pires AP, Silva LZ, Perussi PR, et al. Survey of Cryptococcus neoformans in pigeon (Columbia livia) excreta in public Square in Umuarama, Paraná, Brazil. African J Microbiol Res. 2016; 10(44):18441844. DOI: $10.5897 / A J M R 2016.8253$

4. Rosario I, Acosta B, Colom MF. Pigeons and other birds as a reservoir for Cryptococcus spp. Rev Iberoam Micol. 2008; 25(1):S13-8.
5. Escandón P, De Bedout C, Lizarazo J, Agudelo CI, Tobón Á, Bello S, et al. Cryptococcosis in Colombia: Results of the national surveillance program for the years 2006-2010. Biomédica. 2012; 32(3): 386-98.

6. Escandón P, Montilla A. Tipificación molecular de aislamientos del complejo Cryptococcus neoformans/Cryptococcus gattii. Infectio. 2010; 14(S2):S127-S130.

7. Cogliati M. Global molecular epidemiology of Cryptococcus neoformans and Cryptococcus gattii: An atlas of the molecular types. Scientifica. 2013; 2013(1):1-23.

8. Costa JJ, Freire AK, Aguiar R, Nogueira RS, Araújo FE, Collares DS, et al. Molecular methods for the diagnosis and characterization of Cryptococcus: A review. Can J Microbiol. $2010 ; 56(6): 445-458$.

9. Mak S, Vélez N, Castañeda E, Escandón P. Colombian Environmental Study Group. The Fungus among Us: Cryptococcus neoformans and Cryptococcus gattii Ecological Modeling for Colombia. J Fungi. 2015; 1(3):332-344. 
10. DANE. Proyecciones municipales 2006-2020. [en línea]. 2008. URL Valida en: http://www. dane.gov.co/files/investigaciones/poblacion/ conciliacenso/9ProyeccionesMunicipaleseda dsexo.pdf.

11. Escandón P, Sánchez A, Firacative C, Castañeda E. Isolation of Cryptococcus gattii molecular type VGIII, from Corymbia ficifolia detritus in Colombia. MedMycol. 2010; 48(4):675-678.

12. Casali AK, Goulart L, Rosa e Silva LK, Ribeiro AM, Amaral AA, Alves $\mathrm{SH}$, et al. Molecular typing of clinical and environmental Cryptococcus neoformans isolates in the Brazilian state Rio Grande do Soul. FEMS Yeast Res. 2003; 3:405-415.
13. Meyer W, Castañeda A, Jackson S, Huynh M, Castañeda E. Molecular typing of Ibero American Cryptococcus neoformans isolates. Emerg Infect Dis. 2003; 9:189-195.

14. Quintero E, Castañeda E, Ruiz A. Environmental distribution of Cryptococcus neoformans in the department of Cundinamarca-Colombia. Rev Iberoam Micol. 2005; 22(2):93-98.

15. Callejas A, Ordoñez N, Rodriguez MC, Castañeda E. First isolation of Cryptococcus neoformans var. gattii, serotype $\mathrm{C}$, from the environment in Colombia. Med Mycol. 1998; 36(5):341-4.

16. Agudelo-gonzales S, Murcia-Sanchez F, Salinas D, Osorio J. Infecciones oportunistas en pacientes con VIH en el hospital universitario de Neiva, Colombia, 2007-2012. Infectio. 2015; 19(2):52-59. 